\title{
EFFECT OF AUSTEMPERING TIME ON THE WORKABILITY AND MECHANICAL PROPERTIES OF THE DUCTILE IRON
}

\author{
M. Shaker*, H. Abd El-Hafez ${ }^{* *}$ \\ "Suez Canal University, Faculty of Engineering, 42523 Port Said, Egypt \\ ** Omar Al-Mokhtar University, Faculty of Engineering, Tobruk, Libya
}

\begin{abstract}
The present work was carried out to study the influence of austempering and austempering time on the workability and the mechanical properties of the ductile iron (DI). The results show that, the austempering process increases tensile strength and hardness as well as the workability. Also, the austempering process decreases the ductility and fracture toughness of the ductile iron. Moreover, the effect of austempering time on the mechanical properties was evaluated. It has a slight effect on strength and hardness whereas it has no effect on the fracture toughness. On the other hand, the workability limits are improved with the increase the austempering time. Although the austempered ductile iron has a lower ductility, it still has good toughness. The ductility was improved when the austempering time within the range from 30 to 60 minutes; however it was slight affected above 60 minutes.

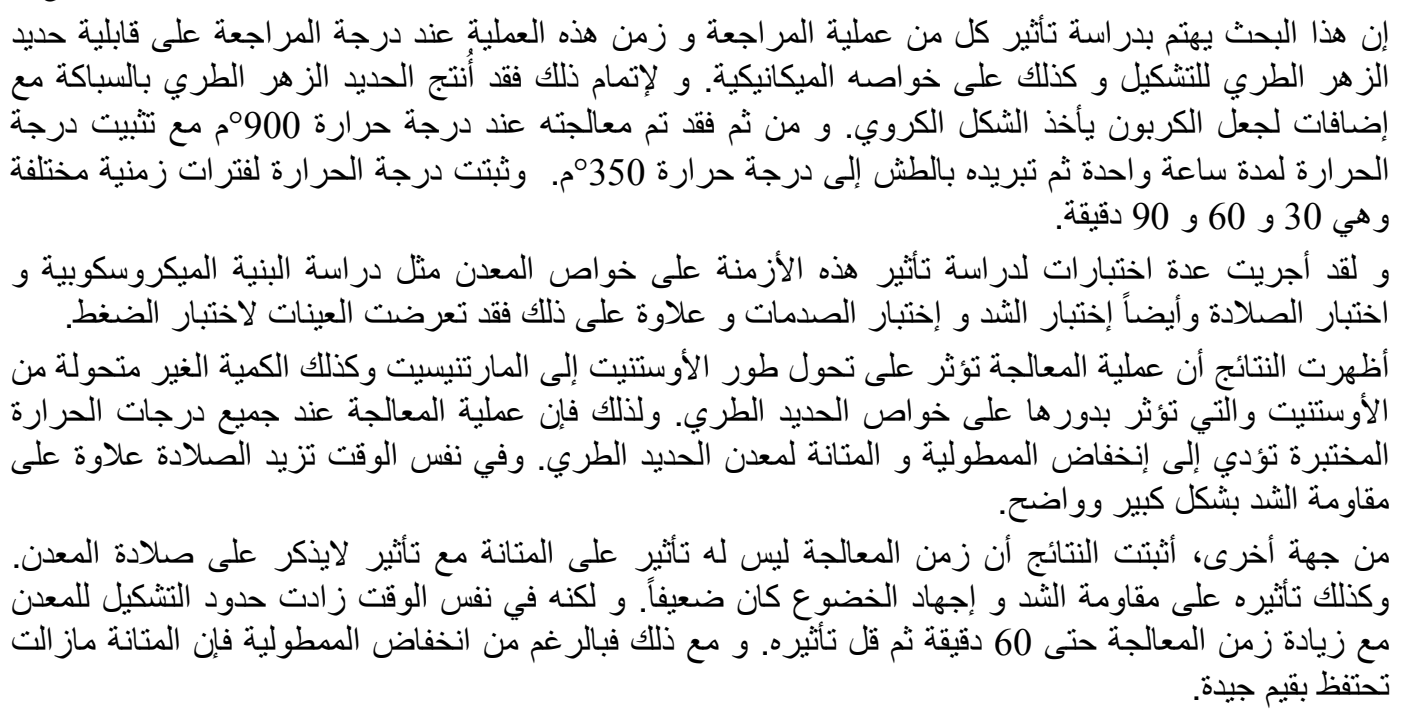

Keywords: Austempering, Ductile iron, Workability, Strength, Toughness.

\section{INTRODUCTION}

Ibrahim et al. [1] claimed that, a combination of high yield strength and high plane strain fracture toughness cannot be obtained in any structural material. However, Austempered ductile iron (ADI) has attracted considerable interest in recent years because of its excellent mechanical properties such as high strength together with good ductility, good wear resistance, and good fatigue properties [2-6].

Other studies [7-12] indicated that this rather new family of engineering materials also offers a great potential for cast parts in applications involving many critical components in automobiles industry, such as crank shafts, steering knuckles and hypoid rear axle gear. The application of these irons is expected to increase in the future, not only in the automobile industry, but also in many other fields such as cast iron parts in applications involving impact loads combined with wear, rail, defense and heavy engineering industries. A combination of very high yield strength and fracture toughness is ideal for structural components, because this will increase the working stress range for load-bearing components.

These attractive properties of ADI are related to its unique microstructure that consists of ferrite and high carbon austenite, which is often referred to as ausferrite [7,13]. Austempering treatment process is normally used for producing such ausferritic structure by austenitizing the casting in a temperature range of $850-950{ }^{\circ} \mathrm{C}$ for sufficient time to get a fully austenitic matrix, and then quenching it in an intermediate temperature range of $250-425^{\circ} \mathrm{C}$. The casting is maintained at this temperature for 2-4 h. Such austempering is often called conventional or 
single-step austempering $[14,15]$. Ductile or nodular cast iron when subjected to austempering heat treatment produces a microstructure consisting of ferrite and high carbon austenite [16].

The mechanical properties of ADI vary depending on the alloying elements added during casting, austenitizing and austempering temperature, and time [17-19]. Austempering temperature is one of the major determinants of the mechanical properties of ADI castings [20].

Once the austempering temperature has been selected the austempering time must be chosen to optimize properties through the formation of a stable structure of ausferrite. At short austempering times, there is insufficient diffusion of carbon to the austenite to stabilize it, and martensite may form during cooling to room temperature [21].

Kumari and Rao [22] investigated the wear behaviour of austempered ductile iron austenitized at $900^{\circ} \mathrm{C}$ for $30 \mathrm{~min}$ and austempered for $2 \mathrm{~h}$ at 260, 280, 300, $320,350,380$ and $400^{\circ} \mathrm{C}$. They concluded that when austempered at temperatures greater than $350^{\circ} \mathrm{C}$, coarse ferrite is was observed to be separated from each other by blocky austenite. At higher austempering temperatures of $350-400^{\circ} \mathrm{C}$, the microstructure consisted of very coarse and feathery ferrite with relatively large amount of bulky austenite. Also, the tendency to form strain induced martensite increased systematically as austempering temperature is was increased. Moreover, formation of the martensite increased the strength of the matrix, and made it more difficult to deform [22].

The ability of austenite to transform to martensite under strain depends on several factors [23], some of which are the carbon content of the austenite, its size and morphology, and its distribution within the microstructure. All these parameters can be varied by varying the heat treatment parameters such as austenitizing temperature and time as well as the austempering time and temperature.

Daber et al. [24] studied the DI behaviour at three austenitizing temperatures, namely 850, 900 and $950^{\circ} \mathrm{C}$ and different austempering temperatures of 300,350 and $400^{\circ} \mathrm{C}$. They proved that the austenitizing temperature of $900{ }^{\circ} \mathrm{C}$ appears to be the optimum, because the best mechanical properties were observed on austenitizing at $900^{\circ} \mathrm{C}$.

Increasing austenitizing temperature increased the tendency for the formation of strain-induced martensite at all austempering temperatures [24].

It has been shown [25] that a high austempering temperature generally results in a microstructure consisting of retained austenite with low stability. Such retained austenite will easily undergo straininduced transformation to martensite, if compared with austenite of ADI austempered at low temperatures. Retained austenite increases as the temperature of austempering increases up to $1 \mathrm{~h} \mathrm{[20].}$ Short austempering time produces a microstructure consisting of ferrite and retained austenite with some martensite; as the austempering time increases, austenite becomes more stable [26]. Retained austenite determines the hardness values of specimens [20].

The greater the amount of upper bainite in the microstructure, the higher will be its tendency to undergo transformation to strain-induced martensite [25].

The experimental work of Rezk et al. [27] indicates that it is possible to obtain a structure consisting of bainite-ferrite and austenite in malleable iron by treatment in the upper-bainite range. The austenite being attained at tempering temperature ranging from $300^{\circ} \mathrm{C}$ to $450^{\circ} \mathrm{C}$, depending on the chemical composition as well as the nodules count [28, 29].

The alloying elements, such as carbon, silicon and copper content, influence in a straight way on microstructure. Also, the hardness, in general, of the casts, is directly related to the chemical composition. Moreover, impact properties of the spherodial graphite cast iron are influenced by the pearlite content [30].

Cracking and defects in metal working processes occur frequently because of the trend toward forming more complex shapes in difficult- to- form alloys. A method of characterizing workability where free surface fracture is dominant, as is the case during upsetting, has been developed for wrought materials [31].

In the present work, the effect of the austempered time on the workability and mechanical properties of the ductile cast iron is investigated.

\section{EXPERIMENTAL WORK}

Total amount of $100 \mathrm{~kg}$ of nearly eutectic gray cast iron, which chemical composition is listed in Table I, was melted in an acidic medium frequency induction furnace. Ferro silicon magnesium alloy $(\mathrm{Fe}, 65 \% \mathrm{Si}$, $9-10 \% \mathrm{Mg}$ ) was used for spheroidization treatment.

The magnesium addition method, used in this investigation, was a vortices method. As shown in Fig. 1. The Fe-Si-Mg alloy was added to the molten metal after melting in a separate small ladle with many holes closed by sheets of aluminum immersed in the molten metal ladle. Then, the Fe-Si-Mg alloy ladle was rotated by an electric motor to permit the $\mathrm{Fe}-\mathrm{Si}-\mathrm{Mg}$ alloy to diffuse in the molten metal to produce a homogenous alloy. The molten alloy was poured in a Y-shaped sand mould. The pouring temperature was kept constant at $1450^{\circ} \mathrm{C} \pm \mathrm{x}^{\circ} \mathrm{C}$ using a platinum-platinum rhodium ( $\mathrm{Pt} / \mathrm{Pt} \mathrm{Rh}-10 \%)$ thermocouple connected to a sensitive mill- 
voltmeter. The Y-bloke casting (JIS.G 5502) is shown in Fig. 2 and its chemical composition is listed in Table II.

Austempering is an especial isothermal heat treatment process that can be applied to ductile cast iron to increase its strength and toughness. Fig. 3 illustrates the isothermal diagram of the used austempering process. The austenitizing and austempering temperatures are chosen as recommended by previous investigations [20,22,24]. Nodular cast iron was first austenitized at $900^{\circ} \mathrm{C}$ for one hour in an electric resistance furnace to get a uniform matrix of austenite [2]. This was followed by quenching in molten salt bath (Nitrate/nitrite) at $350^{\circ} \mathrm{C}$, so a bainitic matrix and retained austenite $(\gamma)$ was formed. The specimens were kept at the austempering temperature for different times $(30,60$, $90 \mathrm{~min}$ ) to determine the austempering time associated with the best mechanical properties. Finally, the specimens were quenched in cold water to room temperature.

The microstructure of the specimens was studied by optical microscopy. Specimens, were also, subjected to Brinell hardness, tensile, impact and upsetting tests. Therefore, Y-blocks were sectioned, machined for specimens preparation for each of these tests.

The metallographic specimens were selected at the center of the block and prepared to the metallographic examination with the usual procedure. Moreover, microscopic study was used to count the nodules per unit area as well as the ferrite percentage.

The tensile test specimens were prepared according to ASTM E8M and tested using a universal testing machine.

To evaluate the fracture toughness, the specimens were tested using impact test. The impact specimens were prepared according to ASTM E399.

Moreover, the workability limits were determined using the upsetting process. The upsetting specimens were prepared in a cylindrical form with different height to diameter ratios $(0.5,1.0$, and 1.5). Barreling of the cylindrical surface, which is a disadvantage for flow stress measurements, actually furnishes considerable flexibility for workability testing. Friction conditions, variation of the contact surface, as well as the cylinder aspect ratio lead to a change of the barrel curvature and, consequently, changing the secondary tensile hoop stress developed at the bulge surface. Thus, the upset can be used to provide a wide range of stresses and strains to evaluate the workability.

Different strain paths were generated by using different height/diameter ratios and friction conditions. To determine the limit strains, the tests were stopped when cracks were observed on the surface of the specimen during the forming process. The final height $\left(\mathrm{H}_{\mathrm{f}}\right)$ and the final diameter $\left(\mathrm{D}_{\mathrm{f}}\right)$ were measured. The diameter was measured in three locations through the specimen height (top, middle, and bottom). The mean diameter, axial and hoop strains were calculated from the following equations.

$$
\begin{aligned}
& \text { Axial strain } \mathrm{e}_{z z}=\ln \left(H_{f} / H_{o}\right) \\
& \text { Hoop strain } \mathrm{e}_{\mathrm{qq}}=\ln \left(D_{f} / D_{o}\right)
\end{aligned}
$$

Where $\mathrm{D}_{\mathrm{o}}$ and $\mathrm{H}_{\mathrm{o}}$ are the initial diameter and initial height of the perform specimen, respectively.

\section{3- RESULTS AND DISCUSSION}

\subsection{Metallographic Examination}

As shown in Fig. 4-a, DI is composed of nodular graphite in a ferritic matrix as a result of the addition of $\mathrm{Fe}-\mathrm{Si}-\mathrm{Mg}$ alloy. The microstructures of ADI generated at different austempering time $(30 \mathrm{~min}, 60$ min and $90 \mathrm{~min}$ ) are shown in Fig. 4 (a, b, c) respectively. The dark areas represent the apparent bainite amount transformed during austempering, while the white areas represent the retained austenite. The apparent bainite areas are composed of lower bainite plates in a needle form and retained austenite captured between the bainite plates.

It is obvious that, the amount of apparent bainite is increasing by increasing the austempering time. The specimen microstructure, at $30 \mathrm{~min}$ in Fig.4-b, shows dark areas representing the martensite and the retained austenite. The martensite structure is very fine and can not be revealed by optical microscope. Specimens with longer holding time have lower bainite and retained austenite only, Fig. (4-c and 4-d).

\subsection{Tensile Test Results}

The yield stress, ultimate tensile strength as well as the elongation percent of ADI at different conditions are presented in Fig.5. It is obvious that, the austempering process has caused the yield stress and tensile strength to increase to more than $100 \%$ However, it seems that most of such strengthening effect has taken place during the early stage of austempering process. Increasing the austempering time for more than $30 \mathrm{~min}$. has little effect on the strength.

On the other hand, the elongation is decreased to about $50 \%$ compared to as-cast DI as a result of the austempering process. Once again, increasing the austempering time for more than $30 \mathrm{~min}$. has little effect on the elongation.

\subsection{Fracture Toughness}

The results obtained from impact test, at different austempering time, are shown in Fig. 6. The results show that the austempering process decreases the toughness of DI. Besides, the austempering time (more than $30 \mathrm{~min}$.) has insignificant effect on the toughness of ADI. 
Since the austenite is a ductile phase, any increase in its retained amount in the matrix is expected to increase the fracture toughness. However, the negligible effect of the austempering time may be due to the insignificant change of the amount of the retained austenite.

\subsection{Hardness Test Results}

The Brinell hardness results of DI, shown in Fig.7, declare a great effect of the austempering process on the hardness. The hardness was increased to about $240 \%$ compared with the as cast. Such increase may be attributed to the transformation of the ferriticpearlitic matrix to the hard martensite phase.

Moreover, austempering time longer than $30 \mathrm{~min}$. has comparatively slight decreases of the hardness values. Such decrease of hardness may be due to the increase of the soft retained austenite on the expense of the martensite hard phase. The hardness increases with structural refinement and decreases with the increase of the amount of retained austenite [32, 33].

\subsection{Workability Limit}

The effect of the austempering time on the workability of ADI illustrated in Fig. 8, represents the workability-limit diagram for free surface fracture in the upsetting-deformation process. It is shown clearly that the austempering process improved the workability limit for the ductile cast iron. The workability limit was increased when the austempering time was increased. The lowest workability limit was obtained when the austempering time was 30 minutes, but insignificant difference is noticed for longer time (60-90 $\mathrm{min})$. However, the workability limit was improved at 60 min. Further increase of the austempering time had insignificant effect. Workability improvement may be attributed, not only to the amount of the retained austenite, but also to its distribution in the matrix.

\section{CONCLUSIONS}

In the present work, the effects of austempering time onto the workability and the mechanical properties of DI were studied. The following conclusions can be drawn from the present investigation.

1- The austempering process has a significant effect on the phase transformations of the ductile iron. The amount of the retained austenite with the martensite phase has a significant effect on the workability limits as well as the mechanical properties of the ductile iron.

2- The austempering process increases the yield and tensile strengths with about 1.5 times of that ascast. This increase may be attributed to the presence of martensite phase with low amount of retained austenite. In the same time, the austempering time has insignificant effect on the strength.
3- The ductility of ADI is lowered to about 50 percent of as-cast DI, whereas slight ductility improvement is noticed with increasing the austempering time.

4- The austempering process decreased the fracture toughness to about 80 percent compared to as-cast DI. Otherwise, the austempering time (longer than $30 \mathrm{~min}$ ) has insignificant effect on the fracture toughness of ADI.

5- The hardness of DI increased to about 2.4 times after austempering for 30 minutes. The hardness is slightly lowered with increasing the austempering time.

6- Longer austempering time improved the workability limits whereas the upper limit is raised only slightly with longer time.

\section{REFERENCES}

[1] Ibrahim K.M., Ibrahim M.M., Noval A.A., and ElSawy A.H. (2008) Effect of alloying addition and two-step austempering on the microstructure and mechanical properties of ductile iron, Proc. $9^{\text {th }}$. Int. conf. mechanical design $\&$ production, Cairo, Egypt, 861-878.

[2] Tayanc M., Aztekin K., Bayram A., (2007) The effect of matrix structure on the fatigue behavior of austempered ductile iron, Materials and Design 28, 797-803.

[3] Dommarco R.C. and Salvanda J.D. (2003) Contact fatigue resistance of austempered and partially chilled ductile irons Wear, vol. 254, 230-236,.

[4] Keough J.R. and Hayrynen K.L. (2006) Developments in the technology and engineering application of austempered ductile iron (ADI), Proceedings of the 8th International Symposium on Science and Processing of Cast Iron, BeijingChina, pp. 474-479.

[5] Garin J.L. and Mannheim R.L. (2003) Straininduced martensite in ADI alloys, Journal of Materials Processing Technology 143-144, 347351.

[6] Putatunda S.K., Kesani S., Tackett R., and Lawes G. (2006) Development of austenite free ADI (Austempered ductile cast iron), Materials Science and Engineering A 435-436, 112-122.

[7] Yang J. and Putatunda S.K. (2005) Effect of microstructure on abrasion wear behavior of austempered ductile cast iron (ADI) processed by a novel two-step austempered process, Materials Science and Engineering A 406, 217228.

[8] Shanmugam P, Rao PP, Udupa N, Venkataraman N. (1994) Effect of microstructure on the fatigue 
strength of an austempered ductile iron. J Mater Sci; 29, 4933-40.

[9] Lerner YS, Kingsbury GR. (1998) Wear resistance properties of austempered ductile iron. J Mater Eng Perform 7(1), 48-52.

[10]Trudel A, Gagne M. (1997) Effect of composition and heat treatment parameters on the characteristics of austempered ductile irons. Can Metall Quart 36(5), 289-98.

[11]Bosnjak B, Radulovic B, Pop-Toner K, Asanovic V. (2001) Influence of microalloying and heat treatment on the kinetics of bainitic reaction in austempered ductile iron. J Mater Eng Perform 10(2), 203-211.

[12] Dai PQ, He ZR, Zheng CM, Mao ZY. (2001) In situ SEM observation on the fracture of austempered ductile iron. Mater Sci Eng A, 319321.

[13]Cakir M.C., Bayram A., Isik Y. and Salar B. (2005) The effects of austempering temperature and time onto the machinability of austempered ductile iron, Materials Science and Engineering A 407, 147-153.

[14] Harding R.A. (2005) The production, properties and automotive applications for austempered ductile iron, Asia-Europe Environment Forum Conference, Jakarta-Indonesia.

[15] Yescas M.A. and Bahdaeshia H.K.D.H. (2002) Model for the maximum fraction of retained austenite in austempered ductile cast iron , Materials Science and Engineering A, A 333, 6066.

[16]Putatunda K., Gadicherla K. (2000) Effect of austempering time on mechanical properties of a low manganese austempered ductile iron, J. Mater. Eng. Perform. 9 (2), PP.193-200.

[17] Tadayonsaidi M., Rao M.H. and Rao G.V.S.N., (2006) Metallurgical properties of retained austenite in ADI at sub-zero temperature, Proceedings of the 8th International Symposium on Science and Processing of Cast Iron, BeijingChina, pp. 151-156.

[18]Zimba J., Simbi D.J. and Navara E. (2003) Austempered ductile iron: an alternative material for earth moving components, Cements\& concrete composites 25, 643-649.

[19] Sahin Y., Edogan M. and Kilici V. (2007) Wear behavior of austempered ductile irons with dual matrix structures, Materials Science and Engineering A, A 444, 31-38.

[20]Cakir M. C., Bayrama A., Isik Y., Salar B. (2005) The effects of austempering temperature and time onto the Machinability of austempered ductile iron, Materials Science and Engineering A 407, 147-153.

[21] Sorelmental, Ductile Iron Data for Design Engineer, Ductile Iron Society, 1990, pp. 84155.

[22] Kumari U.R., P. Rao P. (2009) Study of wear behaviour of austempered ductile iron, J Mater Sci. 44, 1082-1093.

[23] Timokhina IB, Hodgson PD, Pereloma EV (2004) Effect of microstructure on the stability of retained austenite in transformation induced plasticity steels, Metal Mater Trans A 35A, 2331-42.

[24]Daber S, Ravishankar K S, Rao P P, (2008) Influence of austenitising temperature on the formation of strain induced martensite in austempered ductile iron, J Mater Sci. 43, 49294937.

[25]Daber S, Prasad Rao P, (2008) Formation of strain-induced martensite in austempered ductile iron, J Mater Sci. 43, 357.

[26] Baydo gan M., imeno glu H. C, Scand. (2001), J. Metall. 30, 391-395.

[27] Sh. Rezk T., Fargnes J. and Parent Simonin S., (1987) Austempered bainite cast iron with different graphite morphologies", Third Egyptain Foundary conf., Cairo, 145-167.

[28] American Society for Metals, (1964) Heat treatment of cast iron: Metals Handbook, $8^{\text {th }}$. ed., vol. 2, pp. 215- 217.

[29] Truelore G. M., (1975) Heat treatment of ductile iron, Iron worker 39, , pp 22-26.

[30]Gonzaga R.A., Carrasquilla J. F. (2005) Influence of an appropriate balance of the alloying elements on microstructure and on mechanical properties of nodular cast iron, Journal of Materials Processing Technology 162-163, 293-297.

[31] Kuhn H. A. (1977) Workability in hot and cold deformation processes test methods, Criteria and applications: Proc. Symp. On the physical metallurgy of casting, Chicago.

[32] Shelton P.W., and Bonner A.A. (2006) The effect of copper additions to the mechanical properties of austempered ductile iron (ADI), J. material Sci. Proc. Tech. 173, 269-274.

[33] Basso; A., Martinez; R., and Sikora, J., (2006) Development of dual phase ADI, Proc. $8^{\text {th }}$. Int. Sc. Proc. Cast iron, Beijing-China, 408-413. 
M. Shaker and H. Abd El-Hafez, "Effect of Austempering Time on the Workability and Mechanical Properties "

Table I The average chemical composition of eutectic gray cast iron

\begin{tabular}{|c|c|c|c|c|c|c|}
\hline $\mathrm{C}$ & $\mathrm{Si}$ & $\mathrm{Mn}$ & $\mathrm{P}$ & $\mathrm{S}$ & $\mathrm{Cr}$ & $\mathrm{Mo}$ \\
\hline 3.50 & 2.08 & 0.788 & 0.0142 & 0.0142 & 0.0302 & $<.00090$ \\
\hline $\mathrm{Ni}$ & $\mathrm{Al}$ & $\mathrm{Co}$ & $\mathrm{Cu}$ & $\mathrm{Nb}$ & $\mathrm{Ti}$ & $\mathrm{V}$ \\
\hline 0.0196 & .000669 & .00366 & 0.0214 & .00030 & .00401 & .002988 \\
\hline $\mathrm{W}$ & $\mathrm{Pb}$ & $\mathrm{Mg}$ & $\mathrm{As}$ & $\mathrm{B}$ & \multicolumn{2}{|c|}{$\mathrm{Fe}$} \\
\hline$<00.400$ & $<.000300$ & .00207 & .00541 & .00094 & \multicolumn{2}{|c|}{$\approx 93.50$} \\
\hline
\end{tabular}

Table II The average chemical composition of cast ductile iron

\begin{tabular}{|c|c|c|c|c|c|c|c|c|c|}
\hline $\mathbf{C}$ & $\mathbf{S i}$ & $\mathbf{M n}$ & $\mathbf{P}$ & $\mathbf{S}$ & $\mathbf{C r}$ & $\mathbf{M o}$ & $\mathbf{N i}$ & $\mathbf{A l}$ & $\mathbf{C o}$ \\
\hline 3.52 & 2.21 & 0.265 & .00975 & .00398 & 0.0645 & .00695 & 0.0934 & 0.0105 & 0.0188 \\
\hline $\mathbf{C u}$ & $\mathbf{N b}$ & $\mathbf{T i}$ & $\mathbf{V}$ & $\mathbf{W}$ & $\mathbf{P b}$ & $\mathbf{M g}$ & $\mathbf{A s}$ & $\mathbf{B}$ & $\mathbf{F e}$ \\
\hline 0.0881 & .00072 & 0.0144 & 0.0117 & $<0.004$ & $<0.003$ & 0.056 & .00172 & $<.00010$ & rest \\
\hline
\end{tabular}

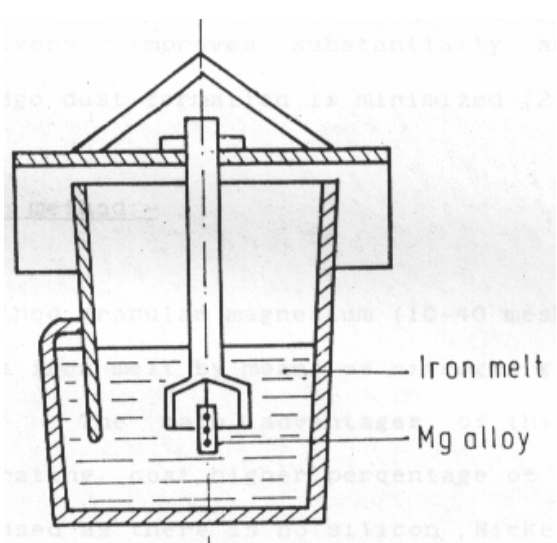

Fig. 1 Melting test rig vortices (Plunging) method
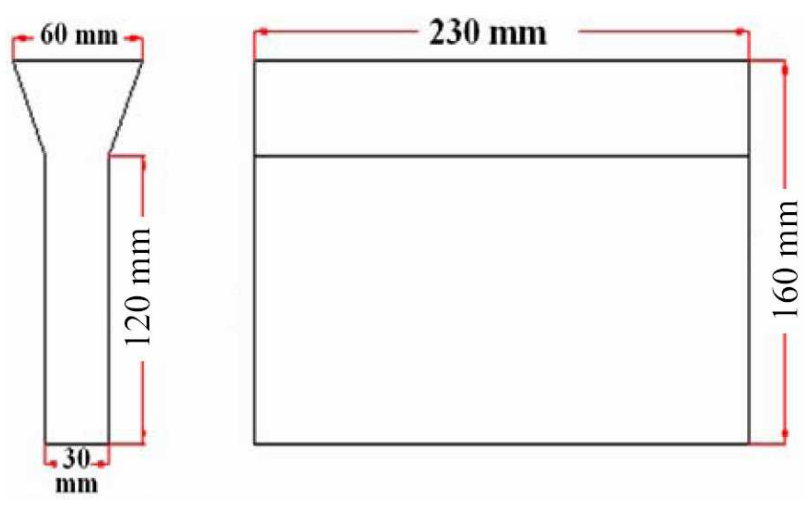

Fig. 2 Cast specimen geometry (JIS.G 5502)

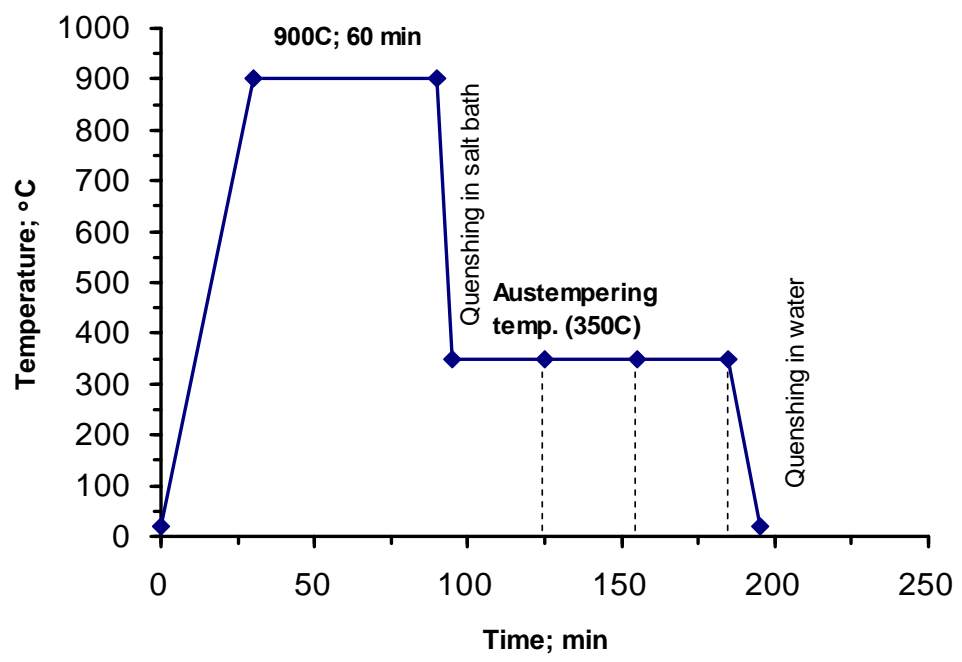

Fig. 3 Schematic isothermal transformation diagram illustrating the austempering process for DI. 


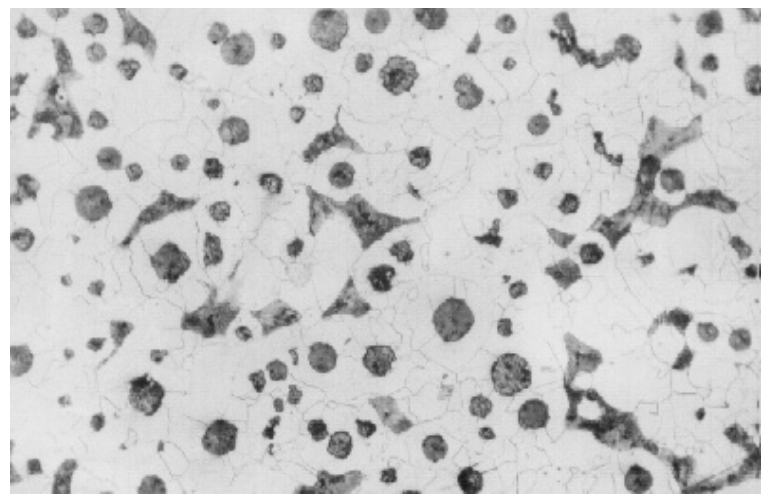

(a) As-cast with $90 \%$ ferrite, $10 \%$ pearlite, 105 Nodule $/ \mathrm{mm}^{2}$ [X100]

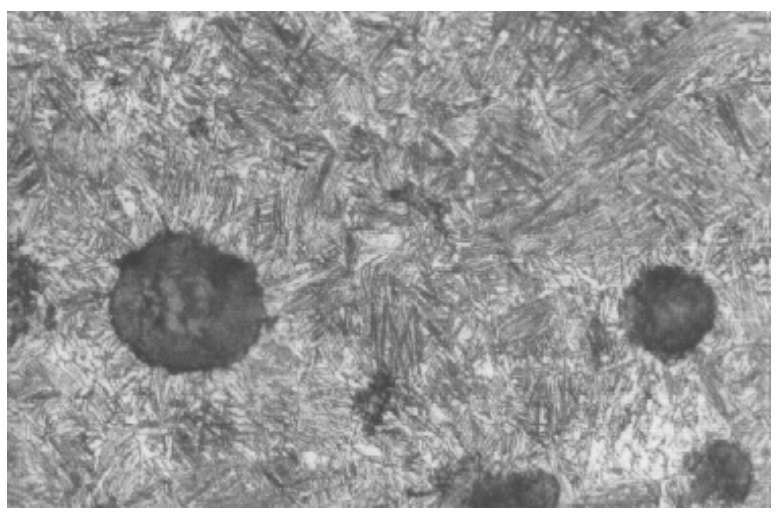

(c) 60 min. (X400)

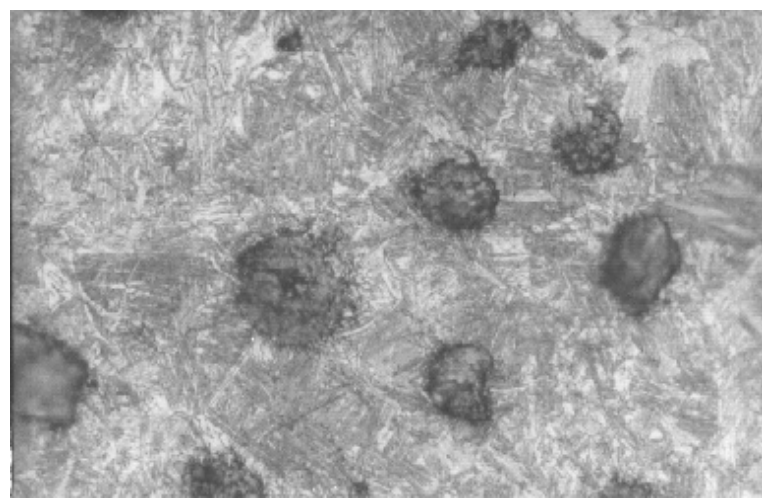

(b) 30 min. (X 400)

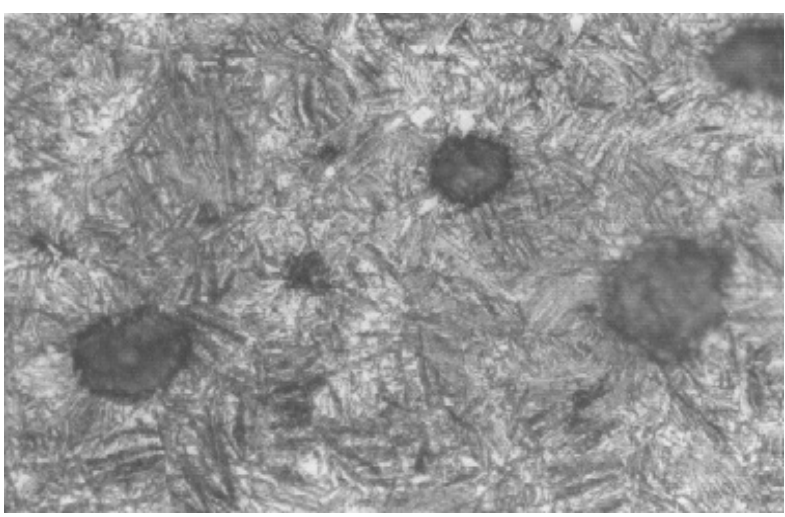

(d) $90 \min (\mathrm{X} 400)$

Fig. 4 Micrographs of ADI at different austempering time.

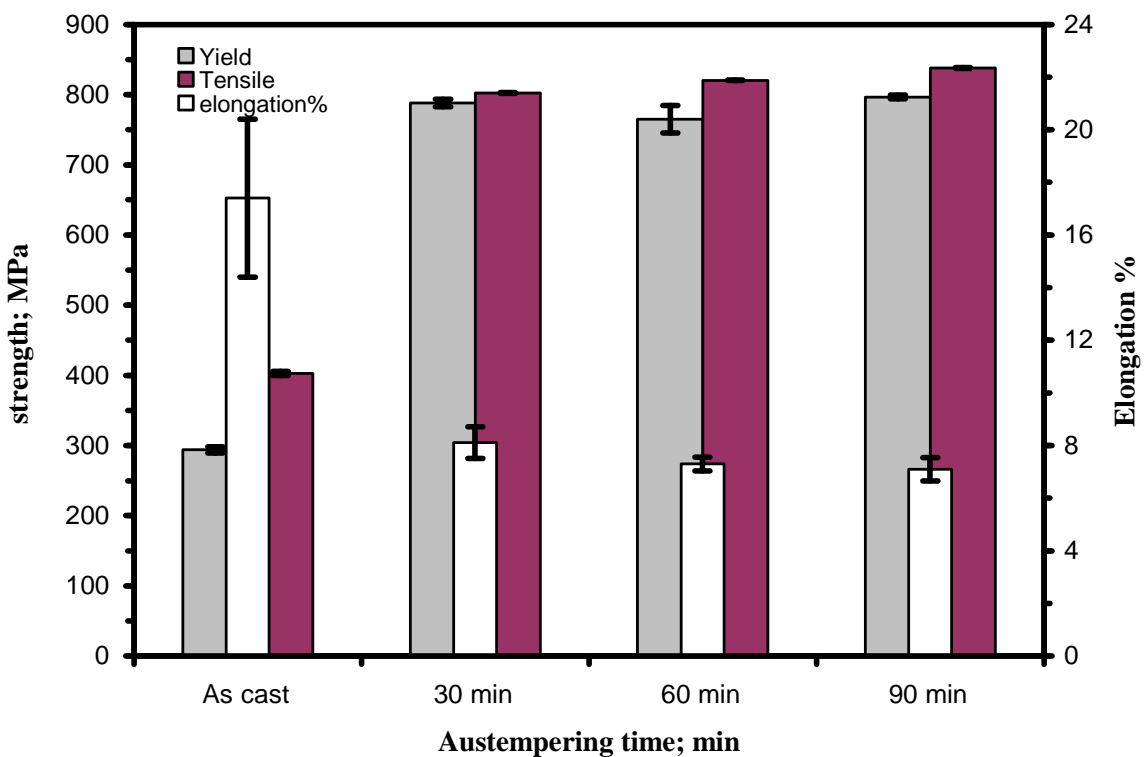

Fig. 5 Effect of austempering time on the yield as well as ultimate strengths and elongation of ADI 


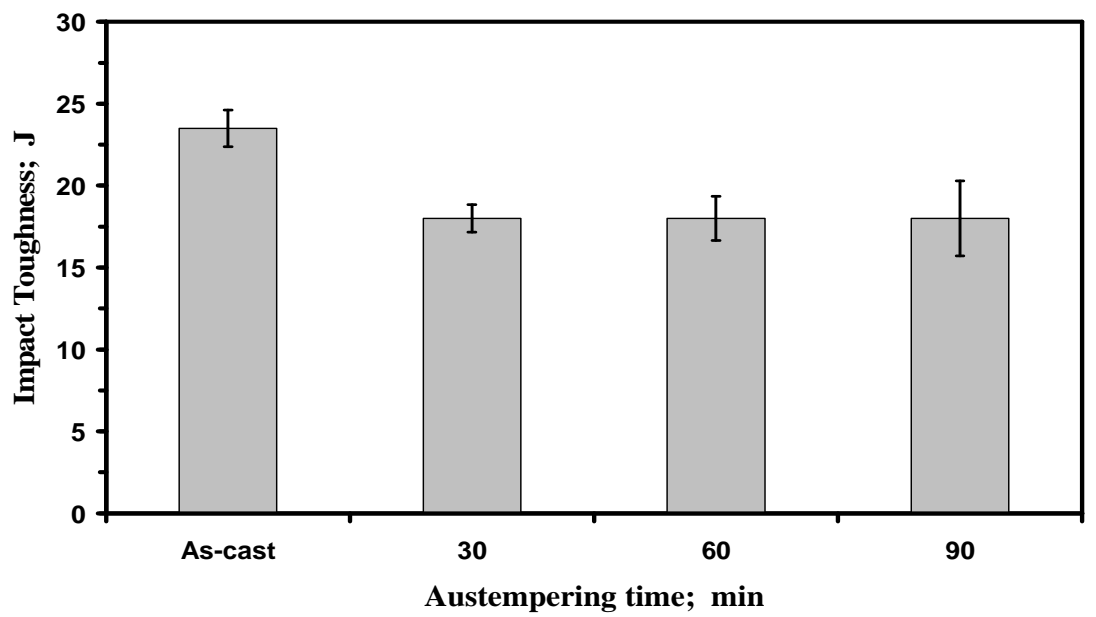

Fig. 6 Effect of the austempering time on the fracture toughness of ADI.

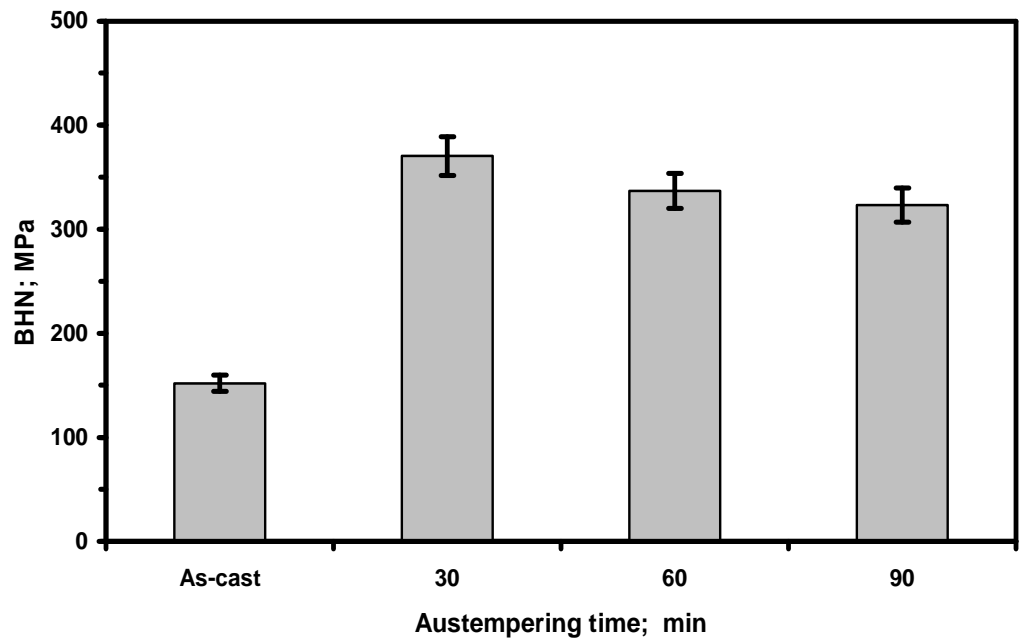

Fig. 7 Effect of the austempering time on the hardness of ADI

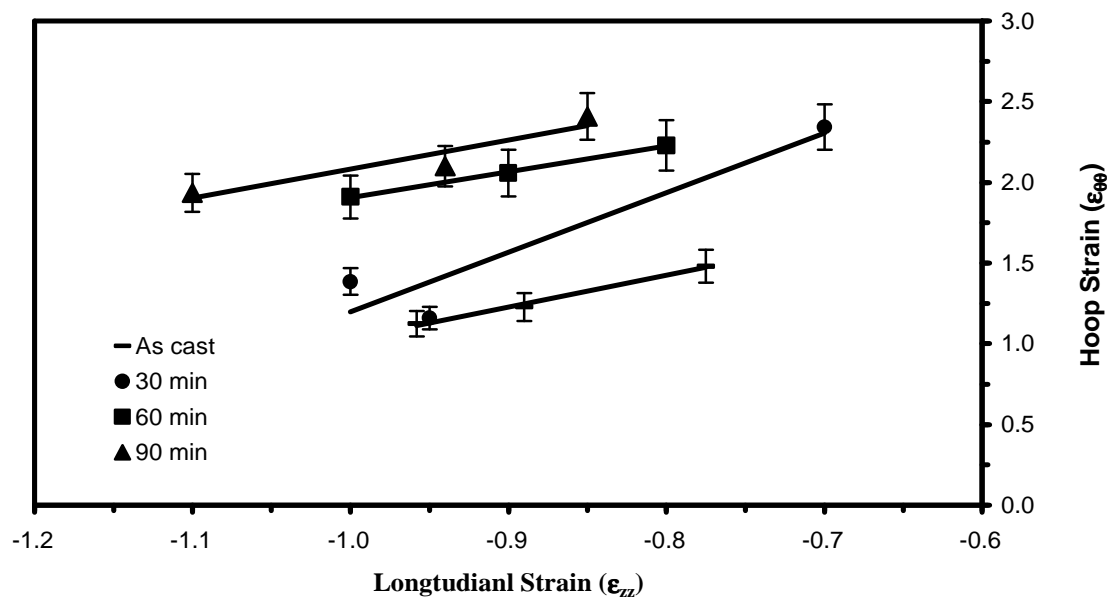

Fig. 8 The effect of the austempering time on the workability limit of ADI 